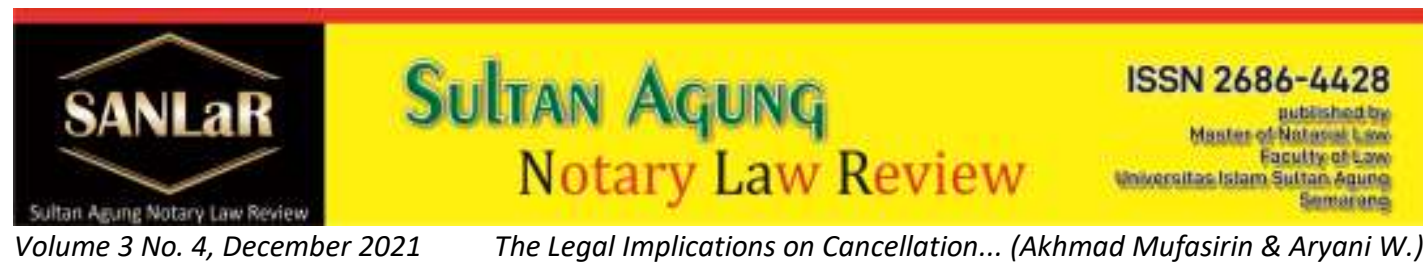

\title{
The Legal Implications on Cancellation of Notaries which can be Canceled by Law
}

\author{
Akhmad Mufasirin ${ }^{*}$ and Aryani Witasari ${ }^{* *}$ \\ ${ }^{*}$ Faculty of Law, Universitas Islam Sultan Agung (UNISSULA) Semarang, E-mail: \\ mufasirin82@gmail.com
}

$\left.{ }^{* *}\right)$ Faculty of Law, Universitas Islam Sultan Agung (UNISSULA) Semarang, E-mail: aryani@unissula.ac.id

\begin{abstract}
The purpose of this study is to analyze and explain the implementation of the cancellation of a notarial deed which can be canceled by law. To analyze and explain the legal implications of the cancellation of a notarial deed.The method used by the researcher is Sociological Jurisdiction and The specifications in this study are descriptive. Based on the results of the study that Implementation of Cancellation of Notary Deeds which can be canceled according to law is the cancellation of notarial deeds can occur due to several things that objective conditions are not fulfilled; absolute incompetence; inability to act; relative incompetence; contrary to the law; public order or decency; fulfillment of legal events in the agreement on the condition that it is void; a defect of will; abuse of circumstances; default as a condition of cancellation; non-fulfillment of formal agreements. Legal Implications for Cancellation of Notary Deed, namely canceled notary deed, cancelable notary deed, and null and void notary deed. 1) A notarial deed that can be canceled is a deed that is canceled by the appearers themselves with a notarial deed based on reasons known to the presenters themselves.
\end{abstract}

Keywords: Implications; Cancellation; Notary; Deed.

\section{Introduction}

The existence of a Notary in Indonesia cannot be separated from the Notary Legal Institution that regulates it. The main role of a notary in Indonesia is to 
regulate legally in writing by pouring the will of his clients into an authentic deed, on the legal relations of the parties requesting his services, it can be said that his function is to provide legal services to the general public in the field of civil law ${ }^{1}$, which includes in the field of public law. In carrying out its functions, the Notary has an impartial and independent position, it is even explicitly stated that the Notary is not a party to the deed, so that the Notary's existence is outside the parties who are his clients. In carrying out their duties, the Notary is regulated by the Act No. 30 of 2004 which has been amended by the Act No. 2 of 2014, replacing the Notary Position Regulation (PJN) which has been in effect since 1860 (Staatsblad 1860 No.3), which is the forerunner of the Notary Legal Institution in Indonesia. In this paper, the author describes the history of the legal institution that began, which is also very closely related to the performance of Notaries in Indonesia. ${ }^{2}$

The position of a notary is based on the trust between a notary and the parties who use his services. ${ }^{3}$ Therefore, he can only give, show, or notify the contents of the deed, grosse deed, minuta deed, copy of deed/deed excerpt to people who have a direct interest or parties named in the deed, heirs.

Notary as one of the legal professions is one of several elements in the implementation of law which part of its authority is to issue a document in the form of a deed with the power as an authentic deed. ${ }^{4}$ Authentic deed is a deed made and inaugurated in legal form, by or before public officials, who are authorized to do so at the place where the deed was made. ${ }^{5}$ The authentic nature of this deed is an element that fulfills the desire for the realization of legal certainty. The authentic deed itself contains a statement of the rights and obligations of a person or individual (in the civil sector) and therefore protects a person in that interest.

The Notary Deed is made in accordance with the will of the interested parties in order to ensure or guarantee the rights and obligations of the parties, certainty, order and legal protection of the parties. The deed essentially makes the truth in accordance with what was notified by the parties to the public official (Notary). The notary has the obligation to include in the deed what has truly been

\footnotetext{
${ }^{1}$ Deen, Thaufiq., Ong Argo Victoria \& Sumain. (2018). Public Notary Services In Malaysia. JURNAL AKTA: Vol. 5, No. 4, 1017-1026. Retrieved from http://jurnal.unissula.ac.id/index.php/akta/article/view/4135

${ }^{2}$ Henny Tanuwidjaja, 2012, Pranata Hukum Jaminan dan Sejarah Lembaga Hukum Notariat, Refika Aditama, Bandung, p. 1

${ }^{3}$ R. Sugondo Notodisoerjo, 1993, Hukum Notariat di Indonesia, Raja Grafindo, Jakarta, p. 13

${ }^{4}$ A. Kohar, 1983, Notaris dalam Praktek, Alumni, Bandung, p. 5.

${ }^{5}$ R. Soegondo Notodisoerjo, 1982, Hukum Notariat di Indonesia, Suatu Penjelasan, Rajawali, Jakarta, p. 41
} 
understood in accordance with the wishes of the parties and to read it to the parties so that the contents of the deed become clear. The statement or statement of the parties by the Notary is stated in the Notary deed. ${ }^{6}$

Based on the problems above, the objectives of this study are as follows: To analyze and explain the implementation of the cancellation of a notarial deed which can be canceled according to law. To analyze and explain the legal implications of the cancellation of a notarial deed.

\section{Research Methods}

In this study, the sociological juridical research method used by the author is a case study research method. ${ }^{7}$ The type of study in this study is more descriptive in nature, which is research that is intended to collect information about the status or existing symptoms, namely the state of the symptoms according to what they were at the time the research was conducted. ${ }^{8}$ The sources and types of data in this study are primary data. And secondary data obtained from literature studies related to the theory of legal responsibility and the theory of legal certainty.

\section{Results and Discussion}

\subsection{Implementation of Cancellation of Notary Deeds which can be Canceled according to Law}

The relationship between this theory of responsibility and the problems that the author describes is that in addition to the Notary exercising his authority as a public official, he has made a good and correct authentic deed and is in accordance with the provisions of the applicable laws and regulations, but does not rule out the possibility that in carrying out his obligations a Notary makes mistakes. In making a deed that causes legal consequences for the parties, if the Notary makes a mistake that harms the parties, the Notary can be held responsible for his mistake. So that this responsibility theory is used to analyze

\footnotetext{
${ }^{6}$ Habib Adjie, 2008, Hukum Notaris di Indonesia-Tafsiran Tematik Terhadap UU No. 30 Tahun 2004 Tentang Jabatan Notaris, Refika Aditama, Bandung, p.45

${ }^{7}$ Robert K. Yin, 2008 : 1 dalam bukunya yang berjudul Studi Kasus, Desain \& Metode, Edisi 1, cet 12, Raja Grafindo Persada, Jakarta, p. 37

${ }^{8}$ Suharsimi Arikunto, 1990, Manajemen Penelitian, Rineka Cipta, Jakarta, p. 309
} 
what can be charged to the Notary as responsibility for the mistakes made by the Notary when carrying out his duties and positions. ${ }^{9}$

Everyone is free to enter into an agreement with anyone, even they are free to determine the form, content and terms of the agreement. However, many ordinary people do not understand that an agreement must meet the legal requirements of the agreement as regulated in Article 1320 of the Civil Code. In this case, if one of the parties to the agreement is harmed, it is very difficult to file a lawsuit, due to the invalidity of the agreement they made. For this reason, the role of a notary is very necessary in making a notarial agreement deed, so that the parties are fulfilled and their goals are achieved so that there is no default in the future. As long as the agreement is still valid, the parties must comply with the articles in the agreement that they have agreed to until the end of the agreement. ${ }^{10}$

In line with the Notary's responsibility for his authority, and his compliance with that authority, legal certainty must be guaranteed on an ongoing basis and with effective supervision and guidance. Currently, there are two notary supervision and development institutions in Indonesia, namely the Notary Supervisory Council and the Notary Honorary Board of the Council. This study uses a normative juridical approach, namely research that is focused on examining the application of norms or norms in positive law. ${ }^{11}$

The notary made a mistake in making the deed. Errors that may occur, namely: a. Typo in the Notary copy, in this case the error can be corrected by making a new copy that is the same as the original and only the same copy as the original has the same power as the original deed. b. Mistake in the form of the Notary deed, in this case where the minutes of the meeting should be made but by the Notary it is made as a statement of the meeting decision. c. Mistakes in the contents of the notary deed, in this case regarding the information and the parties who appear before the notary, where at the time of making the deed it was considered correct but later turned out to be incorrect. ${ }^{12}$

\footnotetext{
${ }^{9}$ Aprilia Putri Suhardini, Sukarmi, Pertanggungjawaban Notaris Yang Melakukan Perbuatan Melawan Hukum Dalam Pembuatan Akta Autentik,. Vol 5 No 1 March 2018, Jurnal Akta Unissula ${ }^{10}$ Sumini, Amin Purnawani, Peran Notaris Dalam Membuat Akta Perjanjian Notariil, Vol. 4 No. 4 December 2017, Jurnal Akta Unissula

${ }^{11}$ Suwardi, The Synchronization Necessary of Notary Supervision by Notary Supervisory and Honour Council, Volume 8 No. 2, June 2021 Nationally Accredited Journal, Jurnal Akta Unissula ${ }^{12}$ Mudofr Hadi, 1991, Varia Peradilan Tahun VI Nomor 72, Pembatalan Isi Akta Notaris Dengan Putusan Hakim, p. 142-143.
} 
There is no definite application of the terms cancellation and cancellation, as described by Herlien Budiono, that: ${ }^{13}$

When the law wants to state that there is no legal consequence, it is stated in the simple term "void", but sometimes uses the term "null and worthless" (Article 879 of the Civil Code) or "has no power" (Article 1335 of the Civil Code). The use of these terms is quite confusing because sometimes the same term will be used for different meanings for "null and void" or "cancellable". In Article 1446 of the Civil Code and so on to declare the cancellation of a legal act, we find the terms "void by law", "cancel it" (Article 1449 of the Civil Code), "demand cancellation" (Article 1450 of the Civil Code), "cancellation statement" (Article $1451-1452$ of the Civil Code), "aborted" (Article 1545 of the Civil Code), and "fallen by law" (Article 1553 of the Civil Code).

The problem of nullity and cancellation by scholars is included in the genus nullitas (nulliteiten), which is a condition where a legal action does not get or cause legal consequences as expected. ${ }^{14}$ If the agreement does not meet the objective requirements, it turns out that there are still claims or demands for this matter, the judge is obliged because of his position, stating that there has never been an agreement or engagement. ${ }^{15}$

A notarial deed is canceled or null and void by law or has the power of proof as an underhand deed occurs because the conditions that have been determined by law are not fulfilled, without the need for certain legal actions from those concerned. Therefore, cancellation is passive, meaning that without any active action or effort from the parties involved in an agreement, it will be null and void by law because immediately there are conditions that are not fulfilled. ${ }^{16}$

Implementation of Cancellation of Notary Deeds which can be canceled according to the law in the City of Surabaya is that the cancellation of notarial deeds can occur due to several things not meeting the objective requirements; absolute incompetence; inability to act; relative incompetence; contrary to the law; public order or decency; fulfillment of legal events in the agreement on the condition that it is void; a defect of will; abuse of circumstances; default as a condition of cancellation; non-fulfillment of formal agreements.

\footnotetext{
13 Herlien Budiono, 2007, Kumpulan Tulisan Hukum Perdata di Bidang Kenotariatan, Citra Aditya Bakti, Bandung, p.364.

14 J. Satrio, 1996, Hukum Perikatan Tentang Hapusnya Perikatan Bagian 2, Cet. I, Citra Aditya Bakti, Bandung, (then abbreviated as J. Satrio I), matter. 165.

${ }^{15}$ R. Subekti, 2005, Hukum Perjanjian, Intermasa, Jakarta, p.22.

${ }^{16}$ Habib Adjie, 2013, Kebatalan dan Pembatalan Akta Notaris, Cet. II, Refika Aditama, Bandung, p. 67
} 
According to the author, the Implementation of Cancellation of Notary Deeds That Can Be Canceled According to the Law is analyzed using the theory of legal responsibility that a person is legally responsible for a certain act or that he bears legal responsibility, the subject means he is responsible for a sanction in the event of a contrary act. . The responsibility of legal subjects or perpetrators who have committed acts against the law or criminal acts to bear costs or losses or carry out crimes for their mistakes or because of their negligence.

\subsection{Legal Implications for Cancellation of Notary Deeds in the City of Surabaya}

Laws enforced by law enforcement agencies assigned to do so must guarantee "legal certainty" for the sake of upholding order and justice in people's lives. Legal uncertainty, will cause chaos in people's lives, and will do each other as they please and act vigilantly. This situation makes life in an atmosphere of social disorganization or social chaos. ${ }^{17}$

In everyday life, there is often an agreement between one individual and another. An agreement that occurs between two or more individuals to perform an action to achieve a common goal is called an agreement. Agreements that are often used in daily life are agreements in oral form without a bond, so that if one party denies then there is no legal sanction. People who want to make a written agreement can be made before a notary. In making an agreement, the parties are free to express the intent and content of the agreement before a Notary, but the problem is that not all Notaries have sufficient legal knowledge and ability to make agreements that are in accordance with the wishes of the client. For this reason, in making a notarial agreement deed, ${ }^{18}$

An agreement according to the provisions of Article 1313 of the Civil Code is an act by which one or more persons bind themselves to one or more other persons. It can be interpreted, from an agreement, obligations or achievements are born from one or more people (parties) to one or more other people (parties) who are entitled to these achievements which constitute an engagement that must be fulfilled by the person or legal subject. ${ }^{19}$

\footnotetext{
${ }^{17}$ M. Yahya Harahap, 2002, Pembahasan Permasalahan Dan Penerapan KUHP Penyidikan dan Penuntutan, Sinar Grafika, Jakarta, p. 76.

${ }^{18}$ Yogi Hanapiah, Sri Endah Wahyuningsih, Hal-Hal Yang Perlu Diperhatikan Oleh Notaris Dalam Membuat Akta Perjanjian Notariil, Vol 5 No 1 March 2018, Jurnal Akta Unissula

${ }^{19}$ Miriam Darus Badrulzaman, 1993, Kitab Undang-Undang Hukum Perdata Buku III Tentang Hukum Perikatan dengan Penjelasan, , cet. 2, Alumni, Bandung, p. 249
} 
In accordance with the legal terms of the agreement according to Article 1320 of the Civil Code, that one of the conditions is the agreement of the parties to bind themselves in the agreement. In this case, an agreement must be deemed born at the time an agreement is reached between the two parties who make the agreement. Furthermore, the person who makes the agreement must state his intention to bind himself. Agreements do not occur if the agreement is made on the basis of coercion, fraud, or oversight. ${ }^{20}$

The need for a notarial institution is inseparable from the need for written evidence in the field of civil law. Given this situation, the notary not only acts as the person who makes authentic evidence but also as the inventor of the law. A notary in his profession is actually an institution that with its deeds creates written evidence tools that have an authentic nature. ${ }^{21}$

Legal Implications for Cancellation of Notary Deed, namely canceled notary deed, cancelable notary deed, and null and void notary deed. 1) a notarial deed that can be canceled is a deed that is canceled by the appearers themselves with a notarial deed based on reasons known to the presenters themselves or based on a court decision for the reasons mentioned in the legal considerations of the relevant decision. The notary can only make a deed of cancellation at the will of the appearers themselves, 2) a notarial deed that can be canceled because the appearers do not meet the subjective requirements of the validity of the agreement, namely agreed and competent, the notarial deed in qualification can be canceled will remain binding on the parties concerned as long as no one submits it. annulment to the Court, 3) a notarial deed which is null and void because the material requirements are not fulfilled or do not meet the objective requirements for the validity of the agreement, namely a certain subject matter and a lawful cause. The legal implication is that it is null and void because the object is not clear or does not exist and can be canceled due to disagreement and competence as stated in Article 1320 of the Civil Code.

According to the author, the Legal Implications for Cancellation of Notary Deeds are analyzed using the theory of legal certainty that legal certainty in certain situations includes; a. Availability of clear and clear, consistent and easy-toobtain legal rules issued by the state power. $b$. That the ruling agencies (government) apply these legal rules consistently and are also subject to and obedient to them. c. That the majority of citizens agree in principle with the content and therefore adjust their behavior to these rules. $d$. That the

\footnotetext{
${ }^{20}$ Abdulkadir Muhammad, 1982, Hukum Perjanjian, Alumni,:Bandung, p. 77.

${ }^{21}$ Yusup Sugiarto, Gunarto, Peran Notaris/PPAT Dalam Pembuatan Surat Kuasa Membebankan Hak Tanggungan Dalam Perjanjian Kredit Pemilikan Rumah (Studi Di Pt. Bank Tabungan Negara Tbk. Cabang Cirebon) Vol 5 No 1 March 2018, Jurnal Akta Unissula
} 
independent and impartial judges (judicials) apply these legal rules consistently when they settle legal disputes. e. That concrete judicial decisions are implemented.

\section{Closing}

Based on the description in the previous chapter, the authors conclude that: 1 ) Implementation of Cancellation of Notary Deed which can be canceled according to law is the cancellation of notary deed can occur due to several things that objective conditions are not fulfilled; absolute incompetence; inability to act; relative incompetence; contrary to the law; public order or decency; fulfillment of legal events in the agreement on the condition that it is void; a defect of will; abuse of circumstances; default as a condition of cancellation; non-fulfillment of formal agreements. 2) Legal Implications for Cancellation of Notary Deed, namely canceled notary deed, cancelable notary deed, and null and void notary deed. 3) A notarial deed that can be canceled is a deed that is canceled by the appearers themselves with a notarial deed based on reasons known to the presenters themselves or based on a court decision for the reasons mentioned in the legal considerations of the relevant decision. The notary can only make a deed of cancellation at the will of the appearers themselves, 4) A notarial deed that can be canceled because the appearers do not meet the subjective requirements of the validity of the agreement, namely agreed and competent, the notarial deed in qualification can be canceled will remain binding on the parties concerned as long as no one submits it.

\section{References}

Journals:

[1] Aprilia Putri Suhardini, Sukarmi, Pertanggungjawaban Notaris Yang Melakukan Perbuatan Melawan Hukum Dalam Pembuatan Akta Autentik,. Vol 5 No 1 March 2018, Jurnal Akta Unissula

[2] Deen, Thaufiq., Ong Argo Victoria \& Sumain. (2018). Public Notary Services In Malaysia. JURNAL AKTA: Vol. 5, No. 4, 1017-1026. Retrieved from http://jurnal.unissula.ac.id/index.php/akta/article/view/4135

[3] Sumini, Amin Purnawani, Peran Notaris Dalam Membuat Akta Perjanjian Notariil, Vol. 4 No. 4 Desember 2017, Jurnal Akta Unissula

[4] Suwardi, The Synchronization Necessary of Notary Supervision by Notary Supervisory and Honour Council, Volume 8 No. 2, June 2021 Nationally Accredited Journal, Jurnal Akta Unissula 
[5] Yogi Hanapiah, Sri Endah Wahyuningsih, Hal-Hal Yang Perlu Diperhatikan Oleh Notaris Dalam Membuat Akta Perjanjian Notariil, Vol 5 No 1 March 2018, Jurnal Akta Unissula

[6] Yusup Sugiarto, Gunarto, Peran Notaris/PPAT Dalam Pembuatan Surat Kuasa Membebankan Hak Tanggungan Dalam Perjanjian Kredit Pemilikan Rumah (Studi Di Pt. Bank Tabungan Negara Tbk. Cabang Cirebon) Vol 5 No 1 March 2018, Jurnal Akta Unissula

Books:

[1] Kohar, 1983, Notaris dalam Praktek, Alumni, Bandung

[2] Abdulkadir Muhammad, 1982, Hukum Perjanjian, Alumni,:Bandung

[3] Habib Adjie, 2008, Hukum Notaris di Indonesia-Tafsiran Tematik Terhadap UU No. 30 Tahun 2004 Tentang Jabatan Notaris, Refika Aditama, Bandung,

[4] __ 2013, Kebatalan dan Pembatalan Akta Notaris, Cet. II, Refika Aditama, Bandung

[5] Henny Tanuwidjaja, 2012, Pranata Hukum Jaminan dan Sejarah Lembaga Hukum Notariat, Refika Aditama, Bandung

[6] Herlien Budiono, 2007, Kumpulan Tulisan Hukum Perdata di Bidang Kenotariatan, Citra Aditya Bakti, Bandung

[7] J. Satrio, 1996, Hukum Perikatan Tentang Hapusnya Perikatan Bagian 2, Cet. I, Citra Aditya Bakti, Bandung, (selanjutnya disingkat J. Satrio I),

[8] M. Yahya Harahap, 2002, Pembahasan Permasalahan Dan Penerapan KUHP Penyidikan dan Penuntutan, Sinar Grfika, Jakarta

[9] Miriam Darus Badrulzaman, 1993, Kitab Undang-Undang Hukum Perdata Buku III Tentang Hukum Perikatan dengan Penjelasan, , cet. 2, Alumni, Bandung,

[10] Mudofr Hadi, 1991, Varia Peradilan Tahun VI Nomor 72, Pembatalan Isi Akta Notaris Dengan Putusan Hakim 
[11] R. Soegondo Notodisoerjo, 1982, Hukum Notariat di Indonesia, Suatu Penjelasan, Rajawali, Jakarta

[12] 1993, Hukum Notariat di Indonesia, Raja Grafindo, Jakarta

[13] R. Subekti, 2005, Hukum Perjanjian, Intermasa, Jakarta

[14] Robert K. Yin, 2008 : 1 dalam bukunya yang berjudul Studi Kasus, Desain \& Metode, Edisi 1, cet 12, Raja Grafindo Persada, Jakarta

[15] Suharsimi Arikunto, 1990, Manajemen Penelitian, Rineka Cipta, Jakarta 